\title{
Efficacy of diphtheria and tetanus vaccination in Gaza, Palestine
}

I.H. Al Aswad ${ }^{1}$ and M.E. Shubair ${ }^{1}$

$$
\text { فعَّالية التلقيح ضد الخُناق والكُز از في غزة بفلسطين }
$$

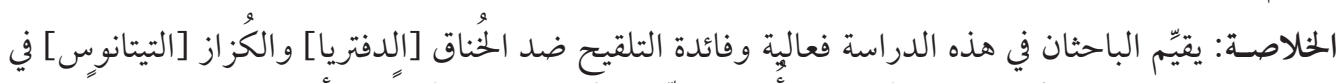

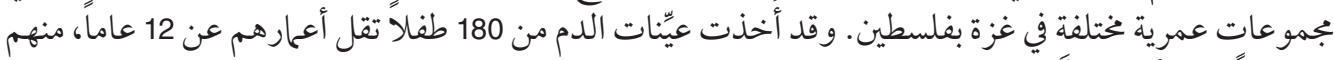

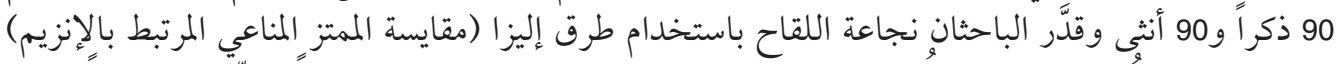

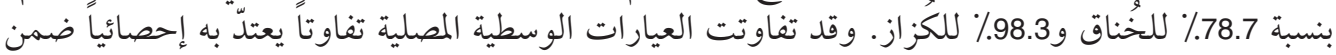

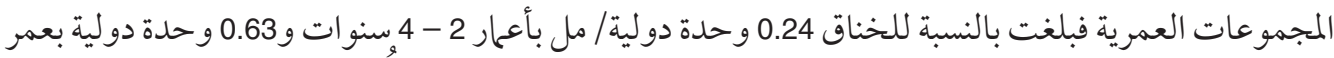

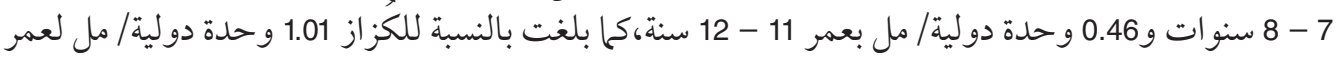

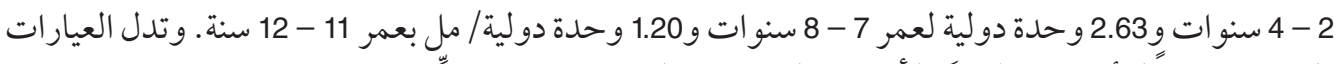

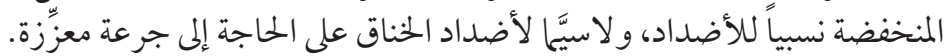

ABSTRACT This study evaluated the effectiveness and usefulness of vaccination against diphtheria and tetanus in different age groups in Gaza, Palestine. Blood samples were collected from 180 children aged $<12$ years, 90 males and 90 females. Using ELISA methods, the efficacy of vaccination was estimated at $87.8 \%$ for diphtheria and $98.3 \%$ for tetanus. Mean serum titres varied significantly by age group: for diphtheria $0.24 \mathrm{IU} / \mathrm{mL}$ at age $2-4$ years, $0.63 \mathrm{IU} / \mathrm{mL}$ at $7-8$ years and $0.46 \mathrm{IU} / \mathrm{mL}$ at $11-12$ years, and for tetanus $1.01 \mathrm{IU} / \mathrm{mL}, 2.63 \mathrm{IU} / \mathrm{mL}$ and $1.20 \mathrm{IU} / \mathrm{mL}$ respectively. The relatively low antibody titres, especially for diphtheria, suggest the need for a booster dose.

\section{Efficacité de la vaccination contre la diphtérie et le tétanos à Gaza (Palestine)}

RÉSUMÉ Cette étude a évalué l'efficacité et l'utilité de la vaccination contre la diphtérie et le tétanos dans différents groupes d'âge à Gaza (Palestine). Des prélèvements sanguins ont été effectués chez 180 enfants âgés de moins de 12 ans (90 garçons et 90 filles). Les techniques ELISA utilisées ont permis d'estimer à $87,8 \%$ l'efficacité de la vaccination contre la diphtérie et à $98,3 \%$ celle contre le tétanos. Les taux d'anticorps sériques moyens variaient significativement selon le groupe d'âge : pour la diphtérie, ils étaient de $0,24 \mathrm{UI} / \mathrm{mL}$ de 2 à 4 ans, $0,63 \mathrm{UI} / \mathrm{mL}$ de 7 à 8 ans et $0,46 \mathrm{UI} / \mathrm{mL}$ de 11 à 12 ans ; et pour le tétanos, respectivement $1,01 \mathrm{UI} / \mathrm{mL}, 2,63 \mathrm{UI} / \mathrm{mL}$ et 1,20 UI/mL. Les taux d'anticorps relativement faibles, notamment pour la diphtérie, semblent indiquer qu'il est nécessaire d'administrer une dose de rappel.

\footnotetext{
${ }^{1}$ Department of Medical Technology, Faculty of Science, The Islamic University, Gaza, Palestine (Correspondence to I.H.Al Aswad: ialaswad@mail.iugaza.edu.ps).

Received: 06/06/06; accepted: 23/11/06
}

المجلة الصحية لشرق المتوسط، منظمة الصحة العالمية، المجلد الخامس عشر، العدد Y، 9 +. 


\section{Introduction}

Although diphtheria and tetanus occur rarely in the world, outbreaks of diphtheria in the former Soviet Union and in several Eastern European countries are a reminder that even a well-controlled infection can re-emerge when herd immunity is not maintained [1]. The epidemic in 1990-93 affected all 15 Newly Independent States, and more than 157000 cases and more than 5000 deaths were reported [2]. A large proportion of adults in many countries are now susceptible to diphtheria. Vaccine-induced immunity wanes over time unless a periodic booster is given or exposure to toxigenic Corynebacterium diphtheriae occurs. The immunity gap in adults coupled with large numbers of susceptible children creates the potential for new extensive epidemics [1].

There are few available studies to evaluate the diphtheria and tetanus vaccination programme in Gaza or neighbouring countries. Swartz et al. studied the immune response to diphtheria and tetanus toxoid components of a combined diphtheria tetanus whole-cell pertussis/enhanced inactivated poliovirus vaccine, administered in a 3-dose schedule to Israeli infants at 2, 3.5 and 10 months of age and followed by a booster dose at the age of 8 years [3]. This was compared with the immune profile of a group of children at the same age given the customary schedule of diphtheria, pertussis and tetanus (DTP) triple-vaccine at 2, 4, 6 and 12 months of age and a booster at age 8 years (control group).

In Gaza the 4 essential doses of the DTP triple-vaccine are given at 2, 4, 6 and 12 months of age, and the DT booster dose is given at school entry, age 6 or 7 years. Our study aimed to assess the efficacy of diphtheria and tetanus vaccines in children aged 2-12 years to evaluate the immunogenicity of the booster dose and to follow up the duration of immunity by measuring the antibody titres in later years and comparing them with the approved level for protection against these diseases

\section{Methods}

This study was conducted from the end of May 2005 to the end of July 2005.

\section{Sample}

The study sample was 180 apparently healthy children from 3 age groups (2-4 years 7-8 years and 11-12 years) who had received the 3 primary doses of DPT vaccine and the 4 th booster dose. The last 2 groups had received the DT booster dose at school entry (6 or 7 years). There were 30 males and 30 females in each group. Children aged 2-4 years old were randomly chosen from the reception department of $\mathrm{Al}$ Naser hospital, where they were attending for problems other than vaccination, while those aged 7-8 years and 11-12 years were chosen from 4 primary schools in Gaza. Both the schools and the children from them were randomly selected. The total number of students in each school was 500-600 and from this number we randomly selected 40-50 students from different age groups until we reach the required number.

The vaccination status for each child was checked from records of the Department of Health. Children were excluded if they had a major congenital defect or serious chronic illness, had any confirmed or suspected immunosuppressive or immunodeficiency condition, or were in receipt of immunoglobulin or blood product therapy.

The percentage of DPT vaccine coverage in 2002 was $100 \%$ for the 3 primary doses and $99.3 \%$ for the booster dose according to the annual report of the Palestinian Ministry of Health [4]. 


\section{Data collection}

Blood samples were collected from each child in a special room in each school with the help of the Directorate of School Health. This study was conducted according to the good clinical practice guidelines and the declaration of the Helsinki Health Research Committee and the Palestinian Ministry of Education. Sample collection was conducted under the supervision of the Directorate of School Health and Al Naser Hospital nursing staff. Before enrolment, the purpose of the study was explained to the child's parents, and then written informed consent was obtained from the parent of every child. Participation rate was high (99.5\%).

\section{Laboratory methods}

A volume of 3-4 $\mathrm{mL}$ of blood was drawn by venepuncture under aseptic conditions and serum was separated by centrifugation. Each sample was distributed into 3 tubes and then stored at $-80^{\circ} \mathrm{C}$ until the time of serological assay.

Antibody titres for diphtheria and tetanus were determined by enzyme-liked immunosorbent assay (ELISA) techniques, which were performed according to the manufacturer's instructions. Two reagents were used in the study: the ELISA kit for diphtheria anti toxoid (Adaltis Italia SpA) and the ELISA kit for tetanus antitoxoid (Adaltis Italia $\mathrm{SpA}$ ). Readings were made using an ELISA reader (TC 89+). According to World Health Organization (WHO) standards, we defined the protective level for both diphtheria and tetanus antibodies as $0.1 \mathrm{IU} / \mathrm{mL}[5,6]$.

The DPT and DT vaccines used in Palestinian vaccination centres are manufactured by Aventis Pasteur and are approved by WHO.

\section{Data analysis}

Data were coded numerically, entered into SPSS, version 8.0 and sorted according to sex and age. The arithmetic mean of antibody titres was calculated for each age group and statistical significance was analysed using 1-way analysis of variance (ANOVA). The percentage of children who had antibody titres $<0.1 \mathrm{IU} / \mathrm{mL}$ and $\geq 0.1$ $\mathrm{IU} / \mathrm{mL}$ was calculated, and statistical significance in vaccination efficacy among age groups and between males and females were analysed using the chi-squared test.

\section{Results}

\section{Diphtheria}

The results showed that overall $87.8 \%$ of children below 12 years old were well immunized against diphtheria and had a protective level of diphtheria antibody ( $\geq 0.1 \mathrm{IU} /$ $\mathrm{mL}$ ). The proportion of children who were protected against diphtheria was $83.3 \%$ among the children aged 2-4 years, $95.0 \%$ for the group 7-8 years and $85.0 \%$ for the group aged 11-12 years (Table 1). There was also a significant difference of protection against diphtheria after the DT booster dose given at 6 years old $(P=0.040)$. The efficacy of diphtheria vaccine not significantly different between the sexes $(83.3 \%$ in boys and $92.2 \%$ in girls, $P=0.069)(\mathrm{Ta}-$ ble 2).

Table 3 shows that the overall mean diphtheria antibody titre was $0.44 \mathrm{IU} / \mathrm{mL}$ $(0.24 \mathrm{IU} / \mathrm{mL}, 0.63 \mathrm{IU} / \mathrm{mL}$ and $0.46 \mathrm{IU} / \mathrm{mL}$ in the 3 age groups respectively). There were significant difference between the 2-4 years and $7-8$ years age groups $(P<0.001)$, the 11-12 years and 7-8 years age groups $(P=0.003)$, and the $2-4$ years and $11-12$ years age groups $(P<0.001)$.

Figure 1 shows the distribution of individual values in each age group.

\section{Tetanus}

Table 1 shows that overall $98.3 \%$ of children had a protective level of tetanus an-

المجلة الصحية لشرق المتوسط، منظمة الصحة العالمية، المجلد الخامس عشر، العدد ب، 9 ج.ب 
Table 1 Protection against diphtheria (DT) and tetanus (TT) among children by age group

\begin{tabular}{|c|c|c|c|c|c|c|c|c|c|}
\hline \multirow[t]{3}{*}{$\begin{array}{l}\text { Age group } \\
\text { (years) }\end{array}$} & \multirow[t]{3}{*}{$\begin{array}{l}\text { No. of } \\
\text { children }\end{array}$} & \multicolumn{4}{|c|}{$\begin{array}{l}\text { Antibody titre }<0.1(\mathrm{IU} / \mathrm{mL} \text { ) } \\
\text { (not protected) }\end{array}$} & \multicolumn{4}{|c|}{$\begin{array}{l}\text { Antibody titre } \geq 0.1(\mathrm{IU} / \mathrm{mL}) \\
\text { (protected) }\end{array}$} \\
\hline & & \multicolumn{2}{|c|}{ DT } & \multicolumn{2}{|c|}{ TT } & \multicolumn{2}{|c|}{ DT } & \multicolumn{2}{|c|}{ TT } \\
\hline & & No. & $\%$ & No. & $\%$ & No. & $\%$ & No. & $\%$ \\
\hline $2-4$ & 60 & 10 & 16.7 & 0 & 0.0 & 50 & 83.3 & 60 & 100.0 \\
\hline $7-8$ & 60 & 3 & 5.0 & 0 & 0.0 & 57 & 95.0 & 60 & 100.0 \\
\hline $11-12$ & 60 & 9 & 15.0 & 3 & 5.0 & 51 & 85.0 & 57 & 95.0 \\
\hline Total & 180 & 22 & 12.2 & 3 & 1.7 & 158 & 87.8 & 177 & 98.3 \\
\hline
\end{tabular}

For $D T \chi^{2}=4.45, d f=2, P=0.108 ;$ for $T T \chi^{2}=6.102, d f=2, P=0.04$.

Table 2 Protection against diphtheria (DT) and tetanus (TT) among children by sex

\begin{tabular}{|c|c|c|c|c|c|c|c|c|c|}
\hline \multirow[t]{3}{*}{ Sex } & \multirow[t]{3}{*}{$\begin{array}{l}\text { No. of } \\
\text { children }\end{array}$} & \multicolumn{4}{|c|}{$\begin{array}{l}\text { Antibody titre }<0.1(\mathrm{IU} / \mathrm{mL}) \\
\text { (not protected) }\end{array}$} & \multicolumn{4}{|c|}{$\begin{array}{c}\text { Antibody titre } \geq 0.1(\mathrm{IU} / \mathrm{mL}) \\
\text { (protected) }\end{array}$} \\
\hline & & \multicolumn{2}{|c|}{ DT } & \multicolumn{2}{|c|}{ TT } & \multicolumn{2}{|c|}{ DT } & \multicolumn{2}{|c|}{ TT } \\
\hline & & No. & $\%$ & No. & $\%$ & No. & $\%$ & No. & $\%$ \\
\hline Male & 90 & 15 & 16.7 & 2 & 2.2 & 75 & 83.3 & 88 & 97.8 \\
\hline Female & 90 & 7 & 7.8 & 1 & 1.1 & 83 & 92.2 & 89 & 98.9 \\
\hline Total & 180 & 22 & 12.2 & 3 & 1.7 & 158 & 87.8 & 177 & 98.3 \\
\hline
\end{tabular}

For $D T \chi^{2}=3.314, d f=1, P=0.069 ;$ for $T T \chi^{2}=0.339, d f=1, P=0.56$.

Table 3 Mean diphtheria (DT) and tetanus (TT) antibody titres among children by age and sex

\begin{tabular}{|c|c|c|c|c|c|c|c|c|c|}
\hline \multirow[t]{3}{*}{ Sex } & \multirow{3}{*}{$\begin{array}{l}\text { No. of } \\
\text { children }\end{array}$} & \multicolumn{8}{|c|}{ Mean antibody titre (IU/mL) } \\
\hline & & \multicolumn{2}{|c|}{ Age $2-4$ years } & \multicolumn{2}{|c|}{ Age $7-8$ years } & \multicolumn{2}{|c|}{ Age $11-12$ years } & \multicolumn{2}{|c|}{ Total } \\
\hline & & DT & TT & DT & TT & DT & TT & DT & TT \\
\hline Male & 90 & 0.22 & 0.90 & 0.72 & 3.23 & 0.45 & 1.15 & 0.46 & 1.76 \\
\hline Female & 90 & 0.26 & 1.11 & 0.55 & 2.02 & 0.47 & 1.26 & 0.43 & 1.46 \\
\hline Total & 180 & 0.24 & 1.01 & 0.63 & 2.63 & 0.46 & 1.20 & 0.44 & 1.61 \\
\hline
\end{tabular}

tibody $(\geq 0.1 \mathrm{IU} / \mathrm{mL})$. All children in age groups $2-4$ and $7-8$ years were protected against tetanus and $95.0 \%$ in age group 11-12 years were protected. Tetanus vaccine efficacy also showed no difference by sex $(97.8 \%$ in boys and $98.9 \%$ in girls, $P$ $=0.56)($ Table 2$)$.

Table 3 shows that the overall mean tetanus antibody titres was $1.61 \mathrm{IU} / \mathrm{mL}$ (1.01 IU/mL, $2.63 \mathrm{IU} / \mathrm{mL}$ and $1.20 \mathrm{IU} / \mathrm{mL}$ in the 3 age groups respectively). There was a significant difference between the 2-4 years and $7-8$ years age groups $(P<0.001)$, and between the 11-12 years and $7-8$ years age groups $(P<0.001)$, but not between the 2-4 years and 11-12 years age groups $(P$ $=0.498)$.

Figure 2 shows the distribution of individual values in each age group.

\section{Discussion}

This study focused on the humoral immune response to diphtheria and tetanus toxoid vaccines in the sera of children below 12 years old. This was accomplished by measuring antibody titres for these toxoids and 

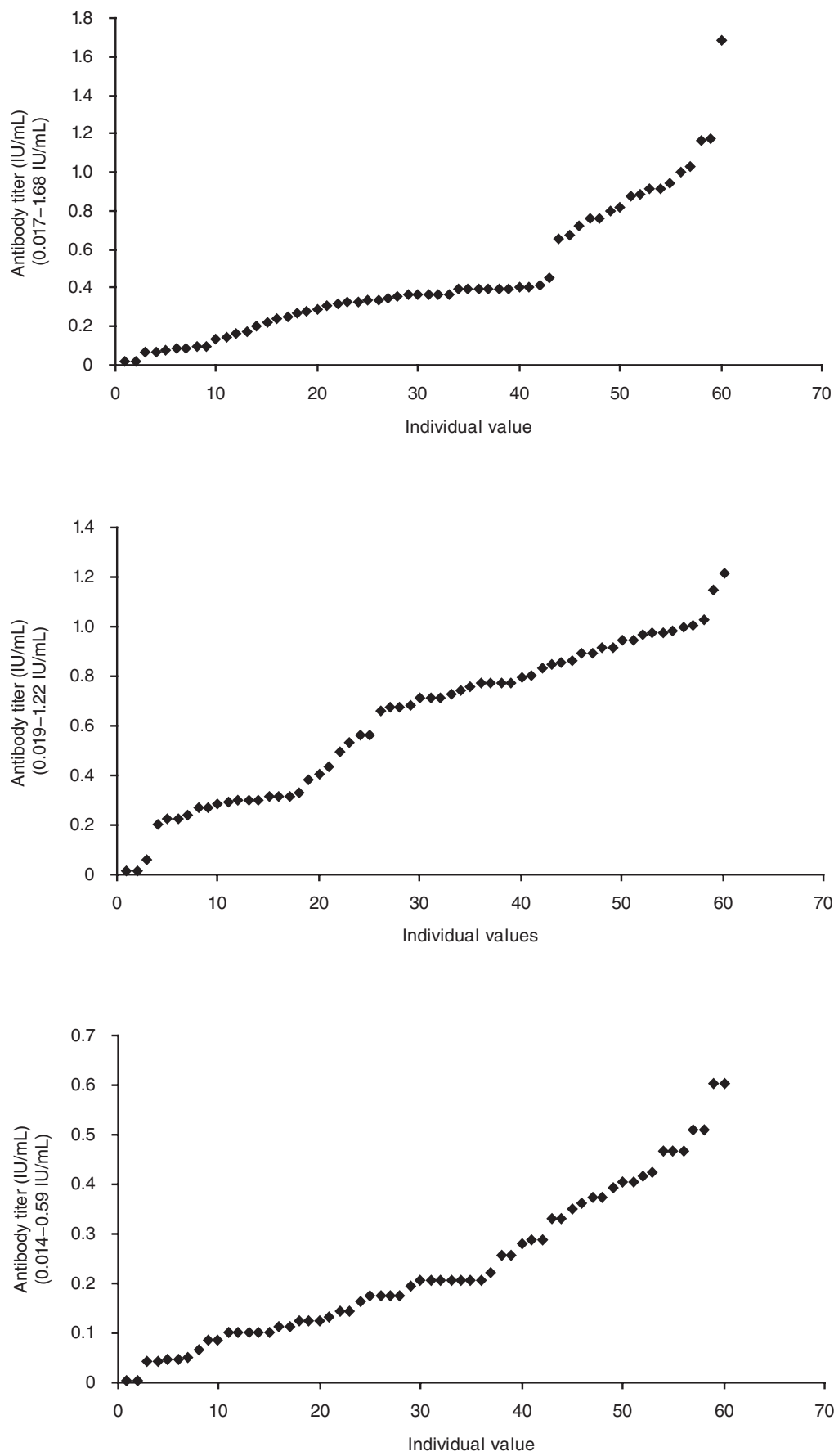

Figure 1 Distribution of individual values for diphtheria toxoid antibody titre among children in the different age groups (a) 2-4 years, (b) 7-8 years, (c) 11-12 years

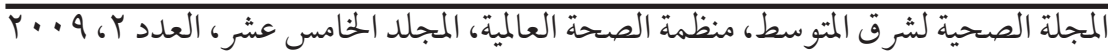



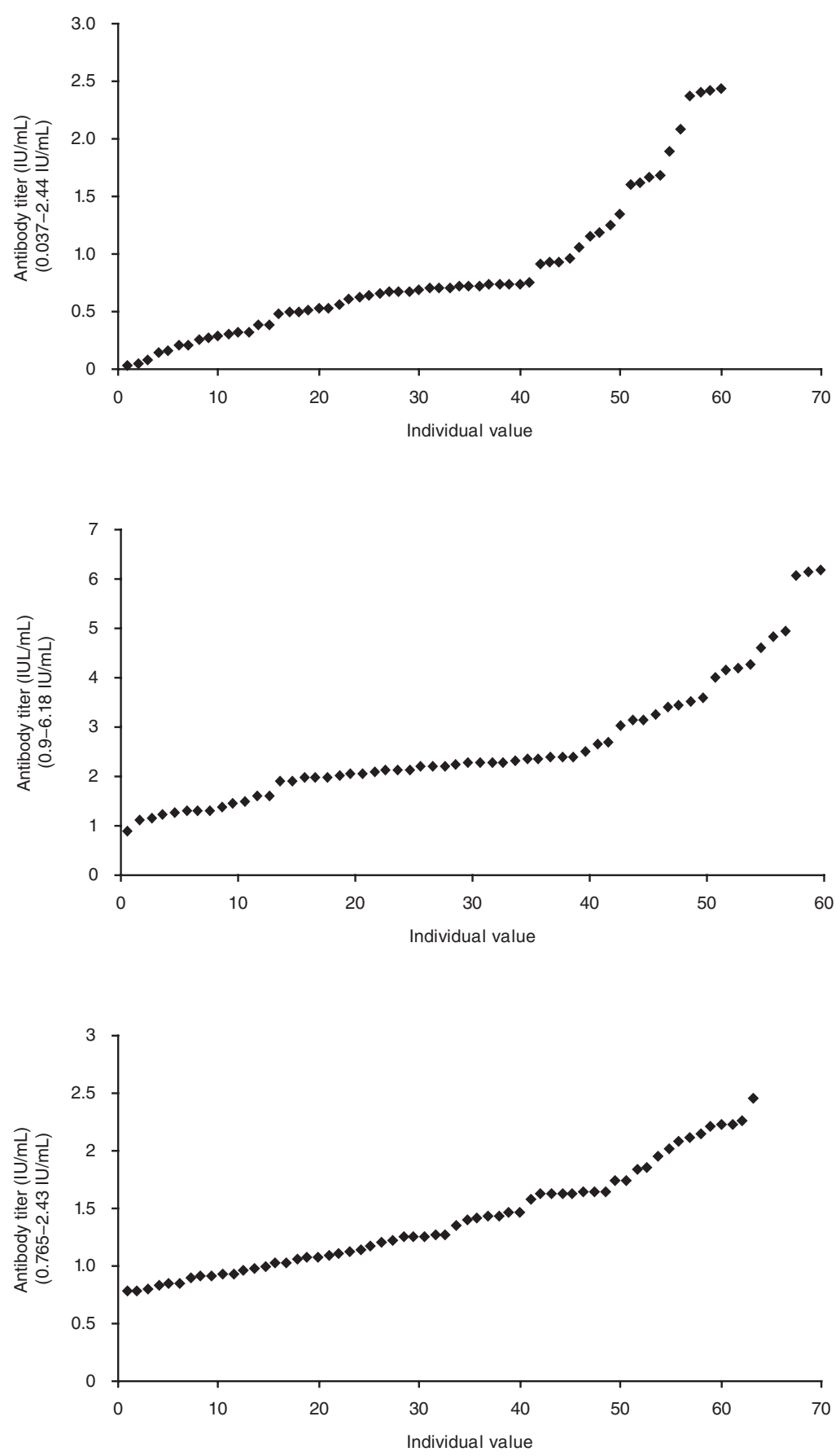

Figure 2 Distribution of individual values for tetanus toxoid antibody titre among children in the different age groups (a) 2-4 years, (b) 7-8 years, (c) 11-12 years 
comparing them with the minimum protective level recommended by WHO for in vitro measurement of both diphtheria and tetanus antitoxoids $(0.1 \mathrm{IU} / \mathrm{mL})[5,6]$. The percentage of children who had titres above and below the protective level was calculated for each age group.

Although diphtheria and tetanus are now rare diseases in Gaza, and no cases have been reported for several years, analysis of serum specimens from children aged under 12 years demonstrated that a considerable proportion of them lack protective levels for diphtheria antibodies. Although DPT vaccine has a high reported coverage in Gaza- $100 \%$ for the 3 primary doses and $99.3 \%$ for the booster dose [4]-12.2\% of children in our sample were not protected against diphtheria and $1.7 \%$ were not protected against tetanus. This raises concern that in an outbreak of diphtheria many people would be at-risk.

Our finding of $87.8 \%$ of children in the different age groups with diphtheria antitoxoid level $\geq 0.1 \mathrm{IU} / \mathrm{mL}$ is lower than the efficacy obtained by McQuillan et al. in the United States, where 91\% of children aged 6-11 years old were protected against diphtheria [7]. Carlsson et al. found $89 \%$ of 5.5year-old Swedish children were protected, a relatively high percentage, despite the fact that those children received only 1 booster dose [8]. Mark et al.'s study of children aged 6, 10 and 16 years old in Sweden revealed that $15 \%, 48 \%$ and $24 \%$ respectively were not protected against diphtheria (antibody titres $<0.01 \mathrm{IU} / \mathrm{mL}$ ) [9]. Their efficacy was low compared with our study.

The efficacy level in our study is also higher than Slusarczyk et al. who studied the immunity of children aged 6-8 years against pertussis, tetanus and diphtheria in Poland. Protective levels were detected in $70 \%, 58 \%$ and $45 \%$ of children aged 6,7 and 8 years respectively [10]. This percentage is low due to the absence of a booster dose at school entry. Lagergård et al. in Sweden determined the neutralizing antibodies and specific immunoglobulin isotype levels in infants after vaccination against diphtheria [11]. Between 6-30 months of age all children were protected, whereas at 30 months only $48 \%$ remained protected. This result is much lower than the results obtained in our study.

While the efficacy of tetanus vaccination in our study was high-98.3\% of children in the different age groups had antitoxoid level $\geq 0.1 \mathrm{IU} / \mathrm{mL}$ and only $1.7 \%$ of children were not protected-this level is in agreement with McQuillan et al. who found that $91 \%$ of children aged 6-11 years were protected against tetanus [7]. It also agreed with Aboud et al. who determined the serological response in children aged 1-15 years immunized with DPT vaccine alone or with a tetanus toxoid booster dose in Tanzania [12]. The percentage of protected children was $94.7 \%$ and $98.0 \%$ at age $1-5$ years and $53.3 \%$ and $55 \%$ at age $6-15$ years in Dar es Salaam and Bagamoyo, Tanzania respectively. Carlsson et al. found that $93 \%$ of the subjects were protected against tetanus [8]. Lower results were obtained by Viviani et al. who evaluated the expanded programme for immunization in The Gambia, and found protective antibody levels in $87 \%$ of $8-9$ year-olds versus $95 \%$ of $3-4$ year-olds [13]. Slusarczyk et al. found that protective tetanus levels were $70 \%, 58 \%$ and $45 \%$ of children aged 6,7 and 8 years respectively [10].

The level of antibody titres declines before the administration of the booster dose and may continue to decrease below the protective level. This agrees with results obtained for diphtheria which indicates that vaccine does not provide individuals with long-term protection. In Schou et al.'s study in Denmark the mean diphtheria

المجلة الصحية لشرق المتوسط، منظمة الصحة العالمية، المجلد الخامس عشر، العدد ب، 9 +. 
antibody titre $(4.1 \mathrm{IU} / \mathrm{mL})$ was higher than in ours $(0.44 \mathrm{IU} / \mathrm{mL})$ [14]. In the study of Björkhom et al. in Sweden the booster dose elevated the mean titre from $0.03 \mathrm{IU} / \mathrm{mL}$ to $1.18 \mathrm{IU} / \mathrm{mL}[15]$, and in the study of Aboud the mean titre for tetanus antitoxoid was $0.82 \mathrm{IU} / \mathrm{mL}$ for age group $1-5$ years, 0.13 $\mathrm{IU} / \mathrm{mL}$ for $6-10$ years and $0.45 \mathrm{IU} / \mathrm{mL}$ for 11-15 years after a booster dose given at 10 years. That study classified participants according to the time after vaccination; in those who received the last dose at $\leq 4$ years the titre was $0.87 \mathrm{IU} / \mathrm{mL}$ and for those aged 4-9 years the titre was $0.29 \mathrm{IU} / \mathrm{mL}[12]$.

The efficacy of diphtheria and tetanus vaccine varies from one research study to another, and differences in these results may be due to several reasons. First, there is the modifying effect of passively-acquired maternal antibodies in young infants which could suppress the development of active immunity following early administration of DPT vaccine. The interference is accentuated in infants who have cord serum titres above $0.1 \mathrm{IU} / \mathrm{mL}[5,6]$.

The endemicity of diphtheria is another reason explaining the variability of results among various studies. In developing countries, a high rate of skin infections caused by C. diphtheriae creates a primary reservoir of diphtheria organisms. This appears to be an important factor in the early development of natural immunity against the disease.

Socioeconomic and sociocultural changes, including improved hygiene and different lifestyles, may also change the epidemiological patterns of diphtheria [16]. Natural immunity against tetanus is one of the most important factors that affect vaccine efficacy; it has been proposed that natural immunity against tetanus can be induced by a sublethal dose of tetanus toxin or by fragments of tetanus toxin released from tetanus bacilli located in the digestive tract, as a result of ingesting tetanus spores [17].
Some authors report finding tetanus antitoxin in the sera of persons who were not immunized. Tetanus toxin can be adsorbed from the gastrointestinal tract [6].

Furthermore, studies have demonstrated that administration of vaccine doses at intervals less than the recommended minimal intervals or earlier than the minimal ages may interfere with antibody response and protection, while increasing the interval between doses of a multidose vaccine does not diminish the effectiveness of the vaccine [18]. The 4th dose in the Gaza schedule is given at 12 months, which is the minimum age recommended. Increasing this age to 15 or 18 months would increase the interval between this dose and the previous one, and enhance better immune response.

Storage and distribution of vaccines also affects the validity of the vaccine; all vaccines are sensitive biological substances and lose their potency with time [19]. Taking into consideration that the electricity supply in Gaza is frequently disconnected, this may explain in part the relatively low efficacy of diphtheria vaccine.

\section{Conclusions}

- The efficacy of tetanus vaccination among children $<12$ years in Gaza is very high $(98.3 \%)$, while that of diphtheria was a little lower $(87.8 \%)$. However, relatively low antibody titres were found after vaccination, which means that vaccine may not give a long-term protection. Hence, it is advisable to give the first booster dose at 15-18 months instead of 12 months in order to increase the response to the booster dose and prolong its duration. Close monitoring of the cold-chain preservation is necessary.

- The DT booster dose which is given at the school entry age is highly immuno- 
genic and raises both vaccine efficacy and antibody titres. The significant difference in both efficacy and antibody titres in both diphtheria and tetanus before and after the reinforcing dose emphasizes the need for such a booster.

- Vaccination efficacy and antibody levels in older children is lower than the younger ones, as seen clearly from the significant difference between the last 2 age groups. Hence, it is necessary to give a DT booster dose at the age of 1314 years and regular booster doses with the combined tetanus-diphtheria toxoid should be routinely given at mid-decade ages and whenever tetanus toxoid is indicated.

\section{Acknowledgements}

We would like to thank the Islamic University, Gaza, for supporting this research.

\section{References}

1. Mattos-Guaraldi AL et al. Diphtheria remains a threat to health in the developing world-an overview. Memorias do Instituto Oswaldo Cruz, 2003, 98(8):987-93.

2. Diphtheria. Chapter 5. In: Epidemiology and prevention of vaccine-preventable diseases. The pink book, Atlanta, Georgia, Centers for Disease Control and Prevention, 2003:55-64, 2003 (http://www. cdc.gov/nip/publications/pink, accessed 1 September 2008).

3. Swartz TA et al. Immune response to a diphtheria and tetanus toxoid administration in a three-dose diphtheria tetanus whole-cell pertussis/enhanced inactivated poliovirus vaccination schedule: a 7-year follow up. European journal of epidemiology, 2003, 18:827-33.

4. Annual report. Gaza, Palestine, Gaza Health Service Division, Ministry of Health, 2002.

5. Galazka A. Immunological basis for immunization, Module 2. Geneva, World Health Organization, 1996 (WHO/EPI/ GEN/93.12).

6. Galazka A. Immunological basis for immunization, Module 3. Geneva, World Health Organization, 1996 (WHO/EPI/ GEN/93.13).
7. McQuillan M et al. Serologic immunity to diphtheria and tetanus in the United States. Annals of internal medicine, 2002, 136(9):660-7.

8. Carlsson RM et al. Antibody persistence in five-year-old children who received a pentavalent combination vaccine in infancy. Pediatric infectious disease journal, 2002, 21(6):535-41.

9. Mark $A$ et al. Immunity and immunization of children against diphtheria in Sweden. European journal of clinical microbiology and infectious diseases, 1989, 8(3):214-9.

10. Slusarczyk J et al. Stan uodpornienia dzieci w wieku 6-8 lat przeciw krztuscowi, tezcowi i blonicy. Immunity of children aged 6-8 against pertussis, tetanus and diphtheria.] Przeglad epidemiologiczny, 2002, 56:39-48.

11. Lagergård $T$ et al. Determination of neutralizing antibodies and specific immunoglobulin isotype levels in infants after vaccination against diphtheria. European journal of clinical microbiology infectious disease, 1992, 11(4):341-5.

12. Aboud S, Lyamuya EF, Kristoffersen EK. Levels and avidity of antibodies to tetanus toxoid in children aged $1-15$ years in 
Dar es Salaam and Bagamoyo, Tanzania. Annals of tropical paediatrics, 2000, 20:313-22.

13. Viviani $S$ et al. C. EPI vaccines-induced antibody prevalence in 8-9-year-olds in The Gambia. Tropical medicine and international health, 2004, 9(10):1044-9.

14. Schou C, Simonsen O, Heron I. Determination of tetanus and diphtheria antitoxin content in dried samples of capillary blood: a convenient method applied to infants. Scandinavian journal of infectious diseases, 1997, 9(4):445-51.

15. Björkholm L et al. Booster effect of low doses of tetanus toxoid in elderly vaccinees. European journal of clinical microbiology and infectious diseases, 2000, 19:195-9.
16. Gunatillake P, Taylor C. The role of cutaneous diphtheria in acquisition of immunity. Journal of clinical microbiology, 1981, 13:83-8.

17. Dastur F, Awatramani V, Dixit JA. Response to single dose of tetanus vaccine in subjects with naturally acquired tetanus antitoxin. Lancet, 1981, 2:219-21.

18. General recommendations on immunization. Chapter 2. In: Epidemiology and prevention of vaccine-preventable diseases. The pink book, 8th ed. Atlanta, Georgia, Centers for Disease Control and Prevention, 2003:9-18.

19. Vaccines and biologicals: Ensuring the quality of vaccines at country level. Geneva, World Health Organization, 2002.

\section{Increasing health literacy in semi-literate to illiterate low income women}

Increasing health literacy in semi-literate to illiterate low income women is a part of Item 3 of the EMRO gender and health activities "Increasing the productive involvement of women and girls in society for maximizing health outcomes" (URL: http://www.emro.who.int/ghd/ activities_womeninvolvement.htm).

Health literacy is recognized as a necessary component to increase positive health outcomes. It reflects the capacity to access and understand basic health information and services and to use that capacity to shape appropriate health care behaviour. Among women and mothers, health literacy is particularly important because of their health promotion roles in the family unit, including the health of children. Mothers provide the first model for children to follow in adopting essential nutritional, hygiene and other health behaviour.

A comprehensive health literacy guide is under development for use in communities in countries of the Eastern Mediterranean Region. The intended target audience is women, especially semi-literate and illiterate mothers with low socioeconomic status. The guide will be administered by trained facilitators to the target audience at the community level. 